\title{
Corporate Governance: The Past, the Present and the Future in Albania
}

\author{
Prof. Assoc. Dr. Sonela Stillo \\ Faculty of Economy, Department of Management, \\ University "Fan S.Noli", Korca, Albania \\ Prof. Dr. Shyqyri Llaci \\ Faculty of Economy, Department of Management, \\ University of Tirana, Albania
}

\section{Doi:10.5901/ajis.2013.v2n9p116}

\begin{abstract}
Corporate have a great impact and importance in the economic, politic, social and cultural aspect of every country. Because of the importance of the corporations, their governance is essential. In Albania, corporate governance is a developing concept, but vital for the promotion of the economic development of the country. In this context, this subject aims to analyze the factors that have influenced in the evolution of the corporate governance, focused mostly at the weaknesses of the corporative governance mechanisms as well as in the relevant cases of governance in the present and in the future.Albania is facing the challenge of attracting the foreign capital during these last years and especially after the crises of 2008. To support and encourage the attraction of foreign investments, it is important the targeting of the cases of corporate governance. The targeting of the governance cases will affect the climate of doing business in Albania, in the conditions when some sectors of the economy are in the way of privatizations of foreign companies. For the realization of this study we did the review of a rich contemporary literature. In addition we analyzed the reports for Albania mainly from the Bank of Albania and international organizations. The results of the study are based in the research over the governance of businesses in the private sector and the public enterprises in Albania. The conclusions of the study will give a full picture over the problematic corporate governance in Albania. In the study we tried to improve the situation through our recommendations toward a positive development climate.
\end{abstract}

Keywords: corporate, governance, private, public, company

\section{Introduction}

Corporate Governance is a field of study with an actual importance and it represents a special interest. Recently, there has been a growth of the interest to understand the mechanisms constituting the Corporate Governance and their impact in the development of the capital market and economic growth. There is no doubt that the academic contribution has allowed us to understand the scope of the Corporate Governance explaining the corporative structures and securing abundant evidence related to their consequences. Such factors as globalization, integration of financial markets, process of privatization and an active participation of institutional investors and stakeholders; promote the need for a better governance of the corporations. Corporate Governance actually comes out as an autonomous discipline, knowing the importance of this subject in global level especially in the last years, where the need for a better Corporate Governance is evident.

Corporate Governance has become a subject of a global politic debate. The international organisms and the governments of different countries have increased their commitment in publishing rules, laws and practices of good governance that aim the returning of confidence in the markets. The need for a good Corporate Governance is essential, in an environment increasingly globalized. Despite the differences between the developed economies and the developing ones, the Corporate Governance cannot be seen as a local issue for the companies, because globalization implies the need for international coordination of the effort to secure a stable growth.

Corporate Governance has drawn attention and it is spreading widely nowadays, all over the world as well as in Albania. Albania is new in the direction of the government of the corporations; however the systems of the government as a time requirement are being built for the improvement of the governance in the joint stock companies. In general, in the developing countries, as it is the case of Albania, these companies are small in number, although it should be noted their increasing tendency the last two decades for example the banks, mobile phones companies, private hospitals, which are 
mainly owned by foreign investors, and a small number of Albanian businesses that under the conditions of globalization tend to rebuilt the structures of their ownership.

Albania is a place where the prosperity and the structure of the joint-stock companies are different if we compare it to other countries of the region. We can classify joint-stock companies in Albania in two large groups: the societies owned by the state or that have just got out of privatization and the private societies created by Albanian or foreign entrepreneurs. In our country is noticed a concentrated structure of ownership. The number of the joint-stock companies is smaller and prevail the societies with family ownership. However the families are generally owners of the little businesses which were not able to become large and powerful societies comparing to the other countries of the region. Regarding to the General Assembly of shareholders, we can say that its function is related mainly to the rights of vote based in the number of the share that every shareholder owns, the selection of the members of the board of the directors, outside auditors, etc. Referring to the disclosure of the information and the transparence in the Albanian companies in most of cases the annual reports contain only the financial mirrors with the relevant records of the authorized accounting experts or audit companies. In the annual reports are not published data about the rewards of the directors or the packet of reward and there is no particular section for the Corporate Governance.

In Albania the Stock Exchange does not exist yet. While the stock exchange of Warsaw was opened since 1817, the stock exchange of Prague since 1871, the stock exchange of Ljubljana since 1024, the stock exchange of Tirana has not started working yet, despite its opening is approved since 1996 (E. Meka, 2007) ${ }^{1}$. This makes the companies not being quoted, the balances are not clear and the foreign entrepreneurs find it difficult to expand their collaboration.

Regarding the board structure, in the Albanian system the board is separated in two levels: the board combines supervising and managing functions. The joint-stock companies in Albania have the opportunity to choose the system with one level or two levels of the board. The Law about Banking provides the banks to be organized according to the system with two levels, where the general meeting of the shareholders appoints the governing council and the members of the directorate. The bank is directed by the directing Council and the directorate. The directing council plays an important role in decision making and surveillance. The bank authorities are: 1) the Assembly of Shareholders; 2) the Directing Council; 3) the Directorate; 4) the Control Committee².

Regarding to the direction and administration in general of the joint-stock companies, there are some problems in Albania, which limit their expansion and growth. One of these is the absence of the culture and the experience in coownership. Today there are a limited number of the businesses in which ownership and management are considered as two separated things and relatively independent of each other. In Albania the Corporate Governance has a different access then the one in the countries in development and the Corporate Governance can be defined as a group of mechanisms that translate or transform the signals of the market of products and market of inputs in behavior of the company.

The main problem of the Corporate Governance in the companies that are controlled by an owner or a family comes as a result of the lack of interest of outside investors for this company. The lack of connections with the capital market leads to operational problems because the owner, who often is the manager, isn't able to recognize and distinguish the signals coming from the market, thus failing in the exploitation of the opportunities. This reduces the value of the company, reducing the demand from the outside company investors to buy a part of the property, because the investors hesitate in buying assets that are little known or for which they will have little control.

Another problem in the governance of the Albanian businesses is the conflict between the owners who have the controlling package and the small owners (primary-primary conflict). The small owners have difficulties in finding third parties interested to buy their share. This thing reduces the value of the opportunities to exit from the ownership in the company. The Albanian laws, as well as the regulatory framework inside the companies offer little defense for the investors who are a minority or who can potentially be a minority. These are two of the reasons holding up the function of the market of the capital in Albania. Under these circumstances, the concentrated structures are inflexible and this is the main problem of the Corporate Governance in Albania.

The relationship between the banks and the companies has been always influenced more by the personal connections than by a careful choice based in the performance of the companies. This is the main reason why the banks have reduced the pace of credit. The personal connections cannot offer protection from the risks of losing, especially when these risks are close by. In Albania has always been impossible to access the correct financial information of a

1 (Llaci 2012), Qeverisja e korporatave

2 (Bankieri 2012), Bankat\&Mirëadministrimi 
company. So another problem is the transparency of the financial information.

"Friend's Capitalism" seems to be a problem as a result of the fact that the dominant owners of many business groups are politically influenced. State authorities and the managers of the companies are closely linked. In practice, the informal connections between the business and the government play an important role bringing different results of the ones that can be created in a normal business course.

Even though no system has ever achieved the perfect Corporate Governance, actually it is required a convergence towards the Anglo-Saxon model with the aim to achieve a great transparence in the markets, growth of the participation of the shareholders, to make BoD's supervising work more efficient and the development of the systems of compensation for the short-term and long-term executives (Cuervo 2002).

According to Raez \& Hossain (2007) the universal model of Corporate Governance does not exist. However, the financial scandals of the corporations, the changing model over the ownership structure and the internationalization of the markets have made possible that many countries and international organizations to develop principles of the Corporate Governance that can be adopted in different contests (Hussain \& Mallin 2002). The capacity of the countries in development to apply a model of Corporate Governance can be connected with the cases of the politic reforms and by the globalization force itself (Barlow \& Clarke 2001) .

\section{The crises in the Corporate Governance}

The term "Corporate Governance took an important place in the economic schedule after the Watergate scandal in USA in 1972, while the years 1980 are considered as the years of the modern era of the Corporate Governance.

A number of factors as: the collapse of the big corporations and the hostile acquisitions especially in UK and USA, the growing power and the antisocial behavior of some corporations have influenced in raising the issue of the Corporate Governance in a global level in the 90's. The issues that have stimulated the interests in the Corporate Governance phenomenon emphasize in particular the causes of the crises of the Corporate Governance.

The crisis in the Corporate Governance culminates in two main moments: first of all the corporative scandals are the largest in the history of the last decades and secondly the presence of the weaknesses in the mechanisms of the Corporate Governance putted the governance of corporations in the spotlight internationally.

The bankrupting of Enron shocked the trust in the corporative culture and in the market mechanisms and it marked a turning point in the discussion about the Corporate Governance. At the same time, other frauds came into light in USA and Europe. But the Enron experience and the reforms were not enough. The financial crisis in 2008 was another corporative collapse, and this time with global dimensions and shocking effects. The reason of this collapse was the real estate bubble in USA, provoked by the way of the banking Corporate Governance and Foreign Investment. The bad governance of the banks and the Foreign Investment were one of the main reasons ok the crisis in USA and in the euro zone. So the bank governance came in first place.

\subsection{Financial crises of 2008}

A report of the OECD states that: "The financial crises can be attributed in a large mass to the failures and the drawbacks of the Corporate Governance 4 ."

Between the main causes of the financial crises in the banking sector we can name:

\subsubsection{The management of the risk in Direction Board level and in managerial level.}

In this context the risks were not identified, valuated and managed in the right way. To the Direction board was served incomplete information that had drawbacks in the right understanding of the risk profile and was not integrated in the right systems for identification, management and reporting of the risk.

3 (Llaci 2012), Qeverisja e korporatave

${ }^{4}$ (OECD 2009), Corporate Governance and the Financial Crisis: Key Findings and Main Messages 


\subsubsection{Compensation and stimulating structures}

The wish for more rewards stimulated the overtaking of the risk, while the Direction board had a lack of independence in monitoring the compensation. There was often showed a lack of transparence and a bad connection with the performance. The objectives of the performance were short termed, little demanding, not linked with the long term stability and had the initiatives based only in the financial indicators.

In 1970 the division between the average wage of the CEOs of the S\&P 500 and the employees was 26:1and 263:1 in 2009. To compare, in Europe the same division is nearly 25:15. Since 1978 to 2011 the wage of the CEOs in the American companies has raised $725 \%$ (127 times faster) while the wage of the employees only $5.7 \%$, according to the data of EPI. In Europe, the inequality is also increasing although this levels cannot be compared with the USA (while in USA the differences are over 400 times, in Germany the division is 12:1, in France 15:1, in UK 22:1, in Hong Kong 44:1 and in Canada 20:1) ${ }^{6}$. Although the difference between the CEO's wage in the index of FTSE 100 in UK and the average wage of the employees raised from 47 times in 1998 in 115 times in 2009 according to MM\&K and Manifest ${ }^{7}$.

\subsubsection{The independence of the board, its qualification and its composition.}

The negative aspect is getting the position of CEO/Board leader by the same person, the lack of financial experience and independence. Large boards, old in age, statistic and restricted commitment of the directors.

\subsubsection{Inactivation of the shareholders}

The shareholders play a non-active role in the improvement of the Corporate Governance, thing that was reflected also in the presence of the non-functional boards with a noted absence of control. The wish for short term profits urged to follow short term interests, doing speculative investments.

\subsubsection{The external audit}

The right commitment of the competences by the external auditor helped the corporations to erase the poor financial conditions, conditioned also by the opportunities in the direction of independence and objectivity in its work. The low objectivity was a result of the concentration in the personal interests and in the low rotation of the audits.

\subsubsection{Rating agencies}

Rating agencies were another crisis factor, because these agencies gave subjective ratings for the corporations with a problem, pushed by the corruptive affairs between them and the corporations

\subsection{The environment of the governance of the banks in Albania during the crises.}

The economic environment in which the banks developed their business changed in a dramatic way as a result of the globalization influenced by neo-liberalism and favorites by the liberalization and the market disruption.

Financial globalization has influenced in the "financialization of the economy", which created the conditions for a large development of the institutional investors. Their entrance in the ownership structure of the companies was the mechanism that has influenced in the evolution of the Corporate Governance of Foreign Investment. Their influence and the managerial adaptation in the new environment explain the evolution of governance of Foreign Investments and their contribution in the financial crisis of year 2008. In the case of the banking sector, financing has had a decisive influence in the inner side of the subjects: it has had changes in Corporate Governance and in the management of banking models.

\footnotetext{
${ }^{5}$ (Executive Excess 2008), The 15th Annual CEO Compensation Survey from the Institute for Policy Studies and United for a Fair Economy.

${ }^{6}$ (Fortune Magazine, November 7th 2011), AFL/CIO CEO Pay Database, 2010

${ }^{7}$ The Manifest/MM\&K Executive Director Survey
} 
Foreign Investments have adapted their business model in this globalized and unregulated environment that is known as "originate-to-distribute", which is directly linked with the financial crises. This model is an effective way to achieve fast break even (Ruingley, 2008) and is developed mostly by the investment banks in countries as USA and UK. So financial globalization has transformed the banking business from the traditional model to the model originate -todistribute and financial innovation. Until the outbreak of the crisis, it was considered as the banking model of the future that would finally replace the traditional model of banking management "buy-and-hold", but today it has been identified as a factor that favored the crises. ACCA states that the bank failures were the government failures.

The private banking system in Albania is relatively new and it has been created almost more than a decade earlier through licensing of the foreign branches and filial, privatization of old state banks and buying new banks by the foreign. At the beginning of the 2000', the banking system in Albania entered in a new phase of development with the entrance in the market of powerful banking groups. During the last 10 years, the banking sector has continued enlarging its activity with big leaps. Actually there are 16 trade banks operating by which $81 \%$ are with private foreign capital and $19 \%$ are with foreign and home capital.

Today the bank assets are about of $95 \%$ of the total financial assets in Albania. In implementation of their strategies, the banks are demanding additional activities and new baking and financial products and services. The effects of the crises in the Albanian economy have often been a hot subject for debate during the last three years. But the experts are joined at one point, that the country has a solid banking system which handled the crisis successfully and was characterized by a noticeable increase of the deposits, increase of problematic loans and important increase of the profits in all the banking system. This has two reasons:

1. Banks in Albania follow the business model of the traditional banking.

2. The establishment of this banking system in a conservative regulatory environment, supervised with exemplary rigor and continuity by the Albanian Bank.

The structure of the shareholder capital of the Albanian banking system and the performance of its main component are shown in tab.1. The importance of this development is an indicator of the readiness of the shareholders to support the banking activity.

Tab.1 The structure of the shareholder capital in the Albanian banking system and the performance of its main component

\begin{tabular}{|c|c|c|c|c|c|c|}
\hline \multirow[b]{2}{*}{ Indicators } & \multicolumn{2}{|c|}{ December 2011} & \multicolumn{2}{|c|}{ December 2010} & \multicolumn{2}{|c|}{ December 2008} \\
\hline & Million lek & $\%$ & Million lek & $\%$ & Million lek & $\%$ \\
\hline Shareholder capital & $97,304.7$ & 100 & $93,138.4$ & 100 & $71,472.1$ & 100 \\
\hline Paid capital & $82,803.9$ & 85.10 & $70,742.0$ & 75.95 & $51,112.7$ & 71.51 \\
\hline
\end{tabular}

\section{Source: Bank of Albania}

The restoring of confidence in the financial system, the stabilized macro-economic situation and the regulative measures of surveillance undertaken by the Albanian bank that aimed passing from "compliance based" in favor of "risk based approach", affected the stabilization and improvement of the indicators of: capitalization, liquidity and profiting of the banking system ${ }^{9}$.

\subsection{The two sides of the privatizations in Albania: CEZ case}

The challenges that Albania is facing in this direction are many and one of the major cases are the privatizations especially in the energy sector and the mines that often have proved that have failed. The situation created in the energy sector of the country, the failure so far of the sensational privatizations of CEZ and ARMO, the problematic created in the first steps of the negotiation of the privatization contract of Albpetrol, are some of the cases of failure of the privatizations. The regulatory entities still can't protect the market and the consummator from the populist politics of the government and from the tendencies for fast profits in the private companies. The most flagrant case in this direction is CEZ. In 2008, the

\footnotetext{
${ }^{8}$ (Buletini i Bankës së Shqipërisë 2011), Studime dhe Artikuj
}

${ }^{9}$ (Bankieri 2012), Bankat\&Mirëadministrimi 
tendering committee chose CEZ for the privatization of OSSH. In March of 2009, CEZ and the government drafted and sign the contract with value $€ 102$ million. CEZ takes possession of $76 \%$ of the shares of OSSH. The report of ERE in 2009: the privatization of CEZ was a failure. The inefficiency was a result of weak management and the level of loses in the network. In 2011, ERE rejected the request of CEZ for raising the price of the energy and METE takes away the regular costumers (heavy industries) from CEZ. CEZ is fined $€ 27$ million by the taxes, $€ 3$ million by ERE. In 23 January 2013, ERE removes its license and CEZ becomes state-owned.

Is raised the question why $\mathrm{CEZ}$ failed in Albania? From the failing reasons we can mention:

- The way of privatization.

- The problems of the contract.

- The improper monitoring by the government and the ERE.

- The relations company-government.

- Mismanagement of the company.

- The energetic sector had a lack of investments and the fees did not fit making the company not to achieve covering the costs.

The failure of CEZ in Albania will be accompanied with serious consequences as for the company, as well as for the Albanian economy, but mostly for the Albanian citizens. We can mention €200 million lost for CEZ and devaluation of the shares. As a result of this misgoverning, there are estimated nearly $\$ 1$ million lost for the Albanian economy. This failure had another negative impact at the business climate in the country and in the foreign investors prejudicing the chances for re privatization and the occurrence of continuous problems in the energy market and in the whole economy.

\section{The initiative for improving the Corporate Governance in Albania}

During the last years there have been made a lot of efforts to promote the improvement of the Corporate Governance in the Albanian companies as in the legal aspect, as well as in the non-legal aspect by various local and foreign institutions. There have been considerable improvements in the regulatory framework to approximate it with international standards ${ }^{10}$. Tab.2.

\begin{tabular}{|c|c|}
\hline Legislative initiatives & Non-legislative initiatives \\
\hline $\begin{array}{l}\text { - The framework of the Corporate } \\
\text { Governance in Albania is } \\
\text { regulated by the law "For the } \\
\text { commercial firms". } \\
\text { - The law "For the titles" (for } \\
\text { companies with public offer). } \\
\text { - The law "For the legal audit" } \\
\text { (auditors and all the companies } \\
\text { that are audited by external } \\
\text { audits). } \\
\text { - The law "For the banks" (in } \\
\text { accordance to the BE directives in } \\
\text { the field of the banking law and } \\
\text { with the principles of Bazel). } \\
\text { - The rules of Tirana stock market. }\end{array}$ & $\begin{array}{l}\text { - The Albanian manual for the corporation governance. } \\
\text { - The Code of the Corporate Governance. The differences in the Law } \\
\text { - } \quad \text { Creation of the "Bridge Bank". } \\
\text { - } \quad \text { Fixation of the mandate of the members of Direction board (4 years). } \\
\text { - The independent members of the Direction board form the majority. } \\
\text { - The law contains some of the principles of the best Corporate } \\
\text { Governance that is expected to improve the implementation of the } \\
\text { Corporate Governance as the approval and the control of the politics and } \\
\text { strategies, monitoring of the efficiency of the managerial practices, the } \\
\text { protection of the interests of the shareholders, of stakeholders, of } \\
\text { depositors, etc. } \\
\text { - The new initiatives of the Albanian bank: } \\
\text { - The strategy of development of the banking surveillance. } \\
\text { New regulations (in accordance with Bazel II). }\end{array}$ \\
\hline
\end{tabular}

Table 2.The improvements in the regulatory framework to approximate it with international standards

As we stated above, there is no doubt that the privatization of the large companies and the public enterprises is the better solution, and generally it brings the desired results, but not always the privatization is possible. Another critical case that we should refer to is finding the adequate methods, implementation of the reforms in the terms of the governance of the public enterprises which have a great impact in the Albanian economy. The public enterprises should apply programs that 
will be crowned with financial and physical results, with growth, efficiency and welfare. Searching for innovation to strengthen the efficiency and effectiveness of management in the public enterprises, we can emphasize a "global consortium for development", thing that is the development goal of the millennium.

The reforms of the government are the most important ways to improve the performance of the public enterprises. With the goal the functioning with effectiveness of the public enterprises, they should be well supervised by a state agency or an independent board. The directing of the enterprise includes the structures and procedures that secure the function with effectiveness and responsibility of the enterprise in the public interest and to contribute in the national development. The role of the governance is to assign the policies, procedures and organizational structures that direct the activity of the public enterprises to achieve these goals.

The analysts of the Albanian economy in their debates about the economic reform often offer solutions that become objects of discussions in the scientific environments and that unfortunately remain in the drawer of the forgotten studies because of the engagement, or because of the insufficient interest of the policy in general. Besides other, one of the cases that are discussed in a permanent way is the degree of independence of the manager in taking the decisions in the public enterprises. Not only in the countries in transition, is the reduction of the intervention of the politic very difficult. The first step in the alleviation of the intervention of the politic would be clarifying the roles of the government as a shareholder, financier, regulator, supplier, client, etc. In Albania all the public enterprises in the form of anonymous companies for cases of economical administration, depend by rule by the directory of the administration of the anonymous societies in the Ministry of economy, while their leadership by the professional view is done by the Ministry depending on whose it is.

The increasing independence of the management of the supervising boards is another success factor in the governance. In Albania the public business has left out of the attention the fact that it should be managed by the rules of the private capital. The main problem is the absence of the managerial concepts. One of the negative phenomena is the short time of residence of the directors in directive posts. According to a study made in the public and private sector it resulted that the average time of residence of the directors in the public sector is 4.3 years, against 6.5 years residence time of the directors in the private business. Exactly the frequent turnover of the high level directors, thanks to the elections and the appointments of the new people with political manners in the administrative hierarchy, divides the innovations and the change. This phenomenon deepens furthermore when there is a inconsistency between the education and the job ${ }^{11}$.

Another success factor is the presence of a relatively independent board. The boards are the axis for the management of the interest through the shareholders, management and other stakeholders, in their efforts to establish the right equilibrium. The corporate boards are dynamic social systems. An effective culture of the board is essential for the effective management of the crisis. Generally in the countries of EJL there are no legal demands for the independent and no executive members of the boards, and there are still some independent board members in the company boards. The building of a solid board is not easy. Even in Albania there is a positive tendency directed to the legislative changes where is predicted a minimal number of independent members. A positive effect is the definition of a limited number of boards where a member can participate aiming this way the increase of the effectiveness of the work of every member.

The transparence is considered as the cornerstone of a serious governance reform. According to the researchers, the financial global crisis of year 2008 despite the preoccupation of the interested parties for transparence, still we can say that the transparence in the financial regulations is mined because the disclosed information is at the same time limited and also excessive. "On the other side, the communications are limited: the determinants of the international standards publish their documents in a limited number of languages (or only in English). Some institutions publish the full texts of answers to the consultants, while other institutions compare and summarize the answers (in the way the consulates consider it as incorrect ${ }^{12)}$

From the studies made in our country, is found that the stock companies see the cases linked with the exposure of the information and over the transparence generally as an answer to the liability for the respect of the legal specific demands that regulates their business. Some of them argue the drawbacks in the publication of the information not only with the non strong legislation demands, but also with the high cost linked with the exposure of the information. Besides this, we note that till now, none of the Albanian companies has been listed, not having so the pressure of the market for

\footnotetext{
11(Stillo 2011), Menaxhimi publik dhe efektiviteti i reformave ne sektorin publik

${ }^{12}$ (C.Bradley 2011), "Transaperncy is the new opacity: Contructing financuial rregullations after the crisis" University of Miami Legal Studies research paper.
} 
the increased transparency. With all the efforts for improvement, we admit that the transparence and the discovery in the countries in transition and especially the countries of the South-East Europe including Albania, despite the progress made, there are still many sharp problems in this field. This situation is partially a product of the last socialist system, where the finances served generally for taxation and statistic purposes and where the information served as an important mean in the contracting of centralized process of planning.

As a conclusion, in Albania is being created a culture of the Corporate Governance and the awareness of the companies is increasing for its importance. But a number of challenges remain such as nepotism, nonfunctional of the market of the capitals, the poor transparence, the relations between the government and the companies, even though there is a legal framework, its applicability constitutes a challenge for the Albanian business. All these cases have the need for attention in the conditions when one of the priorities of Albania is the attraction of the foreign investments, while some important sectors of the economy as the energy and the mines, are on their road to privatization by the foreign companies. It is a demand of the joint-stock companies to follow the principles of good governance by separating the ownership of control, the quality of the direction board, the responsibility over the groups of interest, etc.

\section{References}

(Banka e Shqipërisë 2009, 2010, 2011), Raporti Vjetor i Mbikëqyrjes

(Bankieri 2012), Bankat\&Mirëadministrimi

(Buletini i Bankës së Shqipërisë 2011), Studime dhe Artikuj

(Bradley 2011), Transaperncy is the new opacity: Contructing financuial rregullations after the crisis" University of Miami Legal Studies research paper

(Executive Excess 2008), The 15th Annual CEO Compensation Survey from the Institute for Policy Studies and United for a Fair Economy.

(Fortune Magazine, November 7th 2011), AFL/CIO CEO Pay Database, 2010

(OECD 2009), Corporate Governance and the Financial Crisis: Key Findings and Main Messages

(Stillo 2011), Menaxhimi publik dhe efektiviteti i reformave ne sektorin publik

(Llaci (2012), Qeverisja e korporatave 